\title{
ANALISIS FAKTOR DALAM PEMBERIAN KREDIT YANG BERPENGARUH TERHADAP PERATAAN LABA BANK
}

\author{
Lukmanul Hakim ${ }^{1)}$, Eka Travilta Oktaria ${ }^{2)}$ \\ ${ }^{1)}$ Hukum, Universitas Bandar Lampung \\ 2) Akuntansi, Akademi Akuntansi dan Manajemen Mitra Lampung \\ 1) Jl. ZA Pagaralam, No 26, Labuhan ratu,Bandarlampung \\ 2) Jl. ZA Pagaralam, No 7, Gedong Meneng, Bandarlampung \\ Email : lukman517422@gmail.com ${ }^{1)}$, ekatravilta@yahoo.com ${ }^{2)}$
}

\begin{abstract}
Abstrak
Tujuan utama hadirnya bank adalah untuk mendukung tanggung jawab bersama antar kelompok yang terlibat dengan cara saling bekerja sama dan menjaga seseorang dari risiko yang tak terduga. Saat ini juga bank memainkan peranan yang begitu sangat penting dalam dunia bisnis, tidak hanya perniagaan, manufaktur dan masih banyak kegiatan lain dalam dunia bisnis saat ini yang sangat membutuhkan peranan bank itu sendiri.
\end{abstract}

Sebagai lembaga keuangan, Bank telah terorganisisr secara terstruktur dalam bentuk sebuah perusahaan yang berorientasi pada aspek bisnis yang sangat terlihat dalam era modern saat ini. Seperti kita ketahui juga bank mendapatkan profit atau laba tergantung pada hasil daripada investasi yang dilakukan sesuai dengan skim yang ada dalam bank tersebut.

Perataan laba merupakan salah satu pola manajemen laba.perataan laba dimaksudkan sebagai upaya untuk mengurangi terjadinya fluktuasi laba yang telah dilaporkan oleh pihak manajemen perbankan. Adapun faktor-faktor yang mempengaruhi terjadinya perataan laba yang terdiri dari ukuran perusahaan, return on asset, net profit margin, financia leverage baik secara parsial maupun simultan berpengaruh terhadap perataan laba pada bank.

Kata kunci: Faktor, Kredit, Perataan Laba, Bank.

\section{Pendahuluan}

Dalam dunia bisnis saat ini, semakin banyak perusahaan yang bersaing dengan perusahaan yang lain, salah satunya adalah bank. Dimana banyak masyarakat yang masih beranggapan bank hanya akan memberikan dampak negatif. Mereka yang paham dengan prinsip kerja bank, akan rela menyisihkan sebagian dananya untuk menabung pada bank dengan tujuan membangun asset masa depan.

Tujuan utama hadirnya bank adalah untuk mendukung tanggung jawab bersama antar kelompok yang terlibat dengan cara saling bekerja sama dan menjaga seseorang dari risiko yang tak terduga. Saat ini juga bank memainkan peranan yang begitu sangat penting dalam dunia bisnis, tidak hanya perniagaan, manufaktur dan masih banyak kegiatan lain dalam dunia bisnis saat ini yang sangat membutuhkan peranan bank itu sendiri.

Sebagai lembaga keuangan, Bank telah terorganisisr secara terstruktur dalam bentuk sebuah perusahaan yang berorientasi pada aspek bisnis yang sangat terlihat dalam era modern saat ini. Seperti kita ketahui juga bank mendapatkan profit atau laba tergantung pada hasil daripada investasi yang dilakukan sesuai dengan skim yang ada dalam bank tersebut.

Perusahaan yang ukurannya lebih besar diperkirakan memiliki kecenderungan yang lebih besar untuk melakukan perataan laba (Suwito dan Herawaty, 2005). Berdasarkan political cost hypothesis dalam teori akuntansi positif dikemukakan bahwa perusahaan besar cenderung untuk melakukan pengelolaan atas laba di antaranya melakukan income decreasing saat memperoleh laba tinggi untuk menghindari munculnya peraturan baru dari pemerintah, contohnya menaikkan pajak penghasilan perusahaan.

Juniarti dan Carolina (2005) menyatakan bahwa alasan manajemen melakukan tindakan perataan laba adalah untuk mencapai keuntungan pajak, memberikan kesan baik terhadap kinerja manajemen kepada pemilik dan kreditur, mengurangi resiko sehingga harga sekuritas yang tinggi akan menarik perhatian pasar, untuk menghasilkan laba yang stabil, serta untuk menjaga posisi manajemen dalam perusahaan.

Sebagai salah satu bagian dari informasi keuangan, Menurut Belkaoui (2000) Laporan keuangan merupakan salah satu sumber utama informasi keuangan yang sangat penting bagi sejumlah pemakai dalam pengambilan keputusan ekonomi. Laporan keuangan berperan penting dalam menyampaikan informasi yang dikomunikasikan secara periodik kepada pihak internal maupun pihak eksternal perusahaan sehingga antara keduanya tidak terjadi benturan kepentingan. Yang dimaksud dengan pihak internal yaitu manajemen perusahaan, sedangkan pihak eksternal adalah pemegang saham, kreditor, pemerintah, pemungut pajak, dan pemangku kepentingan lain yang berada di luar perusahaan. Benturan kepentingan yang terjadi antara manajemen dengan pemegang saham merupakan salah satu alasan dilakukannya perataan laba (income smoothing) dalam pelaporan keuangan. Untuk 
menghindari terjadinya hal tersebut maka diperlukan pengendalian yang efektif agar tidak ada pihak yang nantinya akan dirugikan.

Karena itu dengan segala daya dan upaya maka pihak manajemen berusaha keras agar laba yang dihasilkan dapat membuat para pemegang saham untuk terus meningkatkan investasinya. Laba perusahaan berguna sebagai alat untuk menilai kinerja manajemen dari suatu perusahaan. Kinerja manajemen dapat dinilai secara lebih spesifik dengan memperhatikan berbagai faktor, baik faktor yang berasal dari dalam manajemen dan faktor yang berasal dari luar manajemen.

Laba merupakan salah satu informasi potensial yang terkandung di dalam laporan keuangan. Laba perusahaan berguna sebagai penghasilan bagi investor dan orangorang yang berkepentingan di dalamnya sehingga proses produksi dapat terus berjalan dan menghasilkan laba periode berikutnya. Sebagai langkah pertanggungjawaban, maka laba yang dihasilkan oleh perusahaan harus selalu dilaporkan dalam bentuk laporan keuangan untuk mengetahui seberapa jauh prestasi perusahaan tersebut dalam hal pengembalian kepada investor.

She Jin dan Machfoedz (1998) menyebutkan bahwa terdapat pertentangan kepentingan antara kelompok internal dan eksternal yang dapat mendorong timbulnya konflik yang merugikan bagi pihak-pihak yang bertentangan tersebut. Pertentangan dapat terjadi antara pihak-pihak tersebut antara lain:

1. Manajemen berkeinginan meningkatkan kesejahteraannya sedangkan pemegang saham berkeinginan meningkatkan kekayaanya;

2. Manajemen berkeinginan memperoleh kredit sebesar mungkin dengan bunga rendah sedangkan kreditor hanya ingin memberi kredit sesuai dengan kemampuan perusahaan;

3. Manajemen berkeinginan membayar pajak sekecil mungkin sedangkan pemerintah ingin memungut pajak sebesar mungkin.

\section{Pembahasan}

Laba bisa diartikan sebagai arus kekayaan atau jasa yang melebihi keperluan untuk mempertahankan modal konstan. Dalam konsep dasar penghasilan (income) adalah kenaikan manfaat ekonomi selama suatu periode akuntansi dalam bentuk pemasukan atau penambahan aktiva atau penurunan kewajiban yang mengakibatkan kenaikan ekuitas yang tidak berasal dari kontribusi penanam modal. Konsep laba sebagai pengukuran yang fundamental terus-menerus menghadapi tantangan, akan tetapi dilihat dari sudut perspektif informatif konsep laba jelas menggambarkan kegiatan akuntansi. Konsep laba tersebut adalah :

1. Laba sebagai pengukur efisiensi

Efisiensi mempunyai arti yang nyata, paling tidak dalam konsep. Salah satu interpretasi dari efisiensi adalah kemampuan menghasilkan output secara maksimum, relatif terhadap sejumlah resources tertentu atas suatu output yang konstan dengan pemakai resources yang minimal, atau kombinasi dari harga tertentu sehingga menghasulkan return maksimal bagiu pemilik perusahaan.

\section{Laba sebagai alat ramal}

FASB Statement of Financial Concept No.1 menyatakan bahwa investor, kreditor, dan pihak lainnya ingin menilai prospek arus masuk kas bersih perusahaan, tetapi mereka sering menggunakan laba untuk membantu mereka mengevaluasi earning power, untuk meramal laba yang akan datang atau memberikan pinjaman kepada perusahaan.

Dalam SFAC No.1 menyatakan bahwa sasaran utama pelaporan keuangan adalah informasi tentang prestasiprestasi perusahaan yang disajikan melalui pengukuran laba dan komponen-komponennya. Informasi akuntansi keuangan yang dimaksud dalam hal ini adalah informasi laba uang merupakan informasi akuntansi yang terdapat dalam laporan keuangan suatu perusahaan . Informasi ini dapat digunakan oleh pihak intern maupun pihak ekstern perusahaan untuk mengetahui tingkat efektifitas perusahaan dalam memanfaatkan sumberdaya yang ada.

Ukuran yang sering kali dipakai untuk menentukan sukses tidaknya manajemen perusahaan adalah laba yang diperoleh perusahaan. Berhasil atau tidaknya suatu perusahaan pada umumnya ditandai dengan kemampuan manajemen dalam melihat kemungkinan dan kesempatan di masa yang akan datang baik jangka panjang maupun jangka pendek. Investor juga tertarik pada hal yang menyangkut laba yang menjadi haknya yaitu seberapa banyak laba yang diinvestasikan kembali dan seberapa banyak yang dibayarkan sebagai devisa bagi mereka. Hal ini menjadi penting bagi investor untuk mengevaluasi kembali apakah dananya akan diinvestasikan di perusahaan tersebut atau dalam hal ini dipakai sebagai dasar kemampuan perusahaan untuk menghasilkan laba selama periode tertentu.

Perataan laba (income smoothing) terkait erat dengan konsep manajemen laba (earnings manajemen). Penjelasan konsep manajemen laba menggunakan pendekatan teori keagenan ( agency theory) yang menyatakan bahwa praktik manajemen laba dipengaruhioleh konflik kepentingan antara manajemen (agent) dan pemilik (principal) yang timbul ketika setiap pihak berusaha untuk mencapai atau mempertahankan tingkat kemakmuran yang dikehendakinya.

Dalam hubungan keagenan, manajemen memiliki asimetri informasi terhadap pihak-pihak eksternal perusahaan, seperti investor dan kreditor. Asimetri informasi terjadi ketika pemilik sebagai principal tidak dapat memonitor langsung aktivitas manajemen seharihari untuk memastikan manajemen bekerja sesuai dengan keinginan pemilik atay dengan kata lain principal tidak memiliki informasi yang cukup mengenai kinerja agent. Sedangkan manajemen sebagai agent memiliki 
kelebihan informasi mengenai kapasitas diri, lingkungan kerja dan perusahaan secara keseluruhan. Adanya asumsi bahwa individu-individu bertindak untuk memaksimalkan dirinya sendiri, mengakibatkan manajemen memanfaatkan adanya asimetri informasi yang dimilikinya untuk menyembunyikan beberapa informasi yang tidak diketahui pemilik dan untuk menyajikan informasi yang tidak sebenarnya kepada pemilik terutama bila informasi tersebut berkaitan dengan pengukuran kinerja manajemen.

Perataan laba dilakukan dengan tujuan untuk memperbaiki hubungan dengan kreditur, investor dan karyawan serta meratakan siklus bisnis melaluiproses psikologis yaitu:

1. Mengurangi total pajak yang dibayarkan oleh perusahaan.

2. Meningkatkan kepercayaan investor terhadap perusahaan karena laba yang

stabil akan mendukung kebijakan pembayaran deviden yang stabil.

3. Meningkatkan hubungan antara manajer dan karyawan karena pelaporan laba yang meningkat tajam memberi kemungkinan munculnya tuntutan kenaikan gaji dan upah.

4. Siklus peningkatan dan penurunan laba dapat ditandingkan dan gelombang optimisme dan pesimisme dapat diperlunak.

Menurut Gordon (1964) proposisi yang diajukan berkaitan dengan perataan laba adalah kriteria yang digunakan manajemen perusahaan dalam memilih metode akuntansi adalah untuk memaksimumkan kepuasan atau kemakmuran, kepuasan merupakan fungsi dari keamanan pekerjaan, level dan tingkat pertumbuhan besaran (size) perusahaan, kepuasan pemegang saham dan kenaikan performa perusahaan dapat meningkatkan status dan reward bagi manajer dan kepuasan yang sama tergantung pada tingkat pertumbuhan dan stabilitas laba perusahaan.

Aliran perataan laba yang alami (naturally income smoothing) secara sederhana mempunyai implikasi bahwa sifat proses perolehan laba itu sendiri yang menghasilkan suatu aliran laba yang rata. Tipe perataan laba terjadi begitu saja secara alami tanpa intervensi pihak manapun. Berbeda dengan perataan laba yang secara alami, perataan laba yang disengaja (intentionally incomesmoothing) mengandung intervensi manajemen. Ada dua jenis perataan laba yang disengaja, yaitu perataan laba riil dan perataan laba artifisial.

Perataan laba riil menunjukkan tindakan manajemen yang berusaha untuk mengendalikan peristiwa ekonomi yang secara langsung mempengaruhi laba perusahaan di masa yang akan datang. Perataan laba riil mempengaruhi aliran kas. Sebagai contoh, suatu perusahaan dapat memilih proyek permodalan berdasarkan kovari annya dengan serangkaian laba yang diharapkan.
Sedangkan perataan laba artifisial menunjukkan usaha manipulasi yang dilakukan oleh manajemen untuk meratakan laba. Manipulasi yang dilakukan tidak menunjukkan peristiwa ekonomi yang mendasar atau mempengaruhi aliran kas, tetapi menggeser biaya atau pendapatan dari suatu periode ke periode lainnya. Sebagai contoh, suatu perusahaan dapat sevara sederhana meningkatkan atau menurunkan laba yang dilaporkan dengan cara merubah asumsi aktuarilnya yang berkaitan dengan biaya pensiun.

Dari penjelasan tipe perataan laba tersebut, konsep perataan laba yang dimaksud dlaam hal ini adalah perataan laba yang disengaja, tanpa membedakan perataan laba riil atau perataan laba artifisial, karena peneliti hanya meneliti faktor-faktor yang mempengaruhi perataan laba tanpa menguji lebih lanjut bagaimana manajemen melakukan perataan laba tersebut.

Sasaran perataan laba dapat dilakukan terhadap aktivitasaktivitas yang dapat digunakan oleh manajemen untuk mempengaruhi aliran data atau informasi. Dengan kata lain, untuk menciptakan laporan keuangan yang sesuai dengan yang diinginkan, manajer dapat memasukkan informasi yang seharusnya dilaporkan pada periode yang akan datang ke dalam laporan periode ini atau sebaliknya tidak melaporkan informasi periode ini untuk dilaporkan pada periode yang akan datang.

Umur perusahaan berpengaruh terhadap tindakan perataan laba. Hal ini disebabkan karena semakin tingginya umur suatu perusahaan, mencerminkan bahwa sudah semakin kayanya pengalaman perusahaan, sehingga kinerja dari perusahaan tersebut akan cenderung lebih stabil, yang ditunjukkan dengan kestabilan peningkatan dalam pencapaian laba. Sehingga cenderung akan mendorong pihak perusahaan untuk melakukan tindakan perataan laba guna menjaga kestabilan dalam pencapaian laba yang diperoleh.

Oleh sebab itu, tidaklah heran apabila perusahaan yang telah lama berdiri cenderung memiliki tingkat kestabilan profit dibandingkan dengan perusahaan yang baru.

Size tidak berengaruh terhadap tindakan perataan laba. Hal ini disebabkan karena perusahaan perbankan merupakan perusahaan dengan status sebagai media intermediasi, sehingga tidak ada pengaruh berapapun ukuran dari perusahaan bersangkutan, perusahaan tersebut tetap akan menjadi sorotan bagi masyarakat publik. Sehingga tidak ada pengaruh antara jumlah aktiva yang dimiliki perusahaan terhadap tindakan perataan laba yang akan dilakukan. Justru perusahaan perbankan cenderung akan meminimalkan tindakan kecurangan tersebut karena apabila terdeteksi, maka akan menyebabkan terancamnya tingkat likuidasi perusahaan, karena perusahaan perbankan merupakan perusahaan yang bertransaksi dalam bidang keuangan, 
sehingga cenderung lebih mengutamakan kepercayaan dari masyarakat. (Sartika salim : 2013).

Namun dalam kenyataannya banyak perusahaan yang sengaja melakukan praktik manajemen laba untuk memberikan informasi kepada masyarakat bahwa perusahaan mereka masih dalam kondisi yang baik atau sehat, sehingga masih menjaga kepercayaan masyarakat terhadap informasi laporan keuangan yang di hasilkan. Adanya manajemen laba ini didukung oleh PSAK Nomor 1 yang menyebutkan bahwa laporan keuangan harus disusun berdasarkan dasar akrual bukan dasar kas. (ardiana Luthvia : 2017).

\section{Kesimpulan}

Perataan laba bertujuan untuk memperbaiki hubungan dengan kreditur, investor dan karyawan serta meratakan siklus bisnis. adapun konsep dari perataan laba yang pertama Laba sebagai pengukur efisiensi dan yang kedua laba sebagai alat ramal dimana faktor tersebut mempengaruhi perataan laba. Dimana aliran perataan laba yang paling alami secara sederhana memberikan implikasi bahwa sifat proses terhadap perataan laba tersebut dapat menghasilkan laba yang secara nyata.

Dalam pemberian kredit bagi debitur dan memberikan kepercayaan bagi kreditur yang telah memberikan dananya kepada pihak bank dan bank dapat menjaga tingkat kesehatan dan manajemen yang baik sesuai dengan standar operasional prosedur yang berlaku didalam bank tersebut.

\section{Daftar Pustaka}

Ardiana Luthvita Sari, Karakteristik perusahaan, tata kelola perusahaanDan manajemen laba, Jurnal Akuntansi Bisnis, Vol. XVI (No.1) September 2017

Belkaoui, Achmed, Teori Akuntansi,Jilid.2, Salemba Empat, Jakarta, 2000.

Gordon, M. J. Postulates, Principles, and Research in Accounting. The Accounting Review, April, hal 251-263 (1964).

Jin,Liouw She dan Mas'ud Machfoedz. Faktor - Faktor yang Mempengaruhi Praktek Perataan Laba pada Perusahan yang Terdaftar di Bursa Efek Jakarta. Jurnal Riset Akuntansi. Vol.1 no. 2 Juli 1998 : 174 -191 .

Juniarti dan Carolina. Analisa Faktor-Faktor yang Berpengaruh Terhadap Perataan Laba (Income Smoothing) pada Perusahaan-perusahaan Go18 Public. Jurnal Akuntansi dan Keuangan, Vol. 7, No. 2, November 2005:148-162.

Sartika Salim, Rice, Analisis Faktor-Faktor Yang Mempengaruhi Tindakan Perataan Laba Pada Perusahaan Perbankan Di Bursa Efek Indonesia, Jurnal Wira Ekonomi Mikroskil, Volume 3, Nomor 02, Oktober 2013.

Suwito, Edy dan Arleen Herawaty. "Analisis Pengaruh Kharakteristik Perusahaan terhadap Tindakan Perataan Laba yang Dilakukan oleh Perusahaan yang Terdaftar di Bursa Efek Jakarta". Simposium Nasional Akuntansi VIII. Solo. 2005. 